\title{
Mechanism of the beneficial and protective effects of exenatide in diabetic rats
}

\author{
Mohamed Lotfy ${ }^{1,2,3}$, Jaipaul Singh ${ }^{2,4}$, Hameed Rashed ${ }^{5}$, Saeed Tariq $^{5}$, Erika Zilahi ${ }^{6}$ \\ and Ernest Adeghate 5 \\ ${ }^{1}$ Department of Biology, College of Science, United Arab Emirates University, Al-Ain, United Arab Emirates \\ ${ }^{2}$ School of Forensic and Investigative Sciences, University of Central Lancashire, Preston, England PR1 2HE, UK \\ ${ }^{3}$ Hormones Department, National Research Centre, Cairo, Egypt \\ ${ }^{4}$ School of Pharmacy and Biomedical Sciences, University of Central Lancashire, Preston, England PR1 2HE, UK \\ Departments of ${ }^{5}$ Anatomy and ${ }^{6}$ Medical Microbiology, College of Medicine and Health Sciences, \\ United Arab Emirates University, PO Box 17666, Al Ain, United Arab Emirates
}

\author{
Correspondence \\ should be addressed \\ to E Adeghate \\ Email \\ eadeghate@uaeu.ac.ae
}

\begin{abstract}
Glucagon-like peptide 1 (GLP1) agonists are promising therapeutic agents in the treatment of diabetes mellitus. This study examines the mechanism of the protective effects of exenatide in experimental diabetes, employing four groups of ten rats each, in which two groups were streptozotocin-induced diabetic and two were control groups. One control and one diabetic group were treated with exenatide $(1 \mu \mathrm{g} / \mathrm{kg}$ body weight (BW)) for 10 weeks. Blood plasma was taken for biochemical analyses while pancreatic tissue was taken for immunofluorescence and immunoelectron microscopy studies and real-time PCR to examine the expression of genes. The results show that exenatide improved BW gain and reduced blood glucose in diabetic rats compared with controls. Similarly, exenatide enhanced insulin release from the pancreatic fragments and improved liver and kidney functions and lipid profile in diabetic rats compared with controls. Exenatide not only induced significant increases in serum insulin level but also elevated the number of insulin-, GLP1- and exenatide-positive cells compared with untreated controls. Exenatide also elevated the number of catalase- and glutathione reductase-positive cells in diabetic rat pancreas compared with controls. Exenatide caused significant elevation in the expressions of pancreatic duodenal homeobox-1, heat shock protein-70, glutathione peroxidase, insulin receptor and GLP1 receptor genes in the pancreas of both control and diabetic rats compared with untreated animals. The results have demonstrated that exenatide can exert its beneficial and protective effects by elevating the levels of endogenous antioxidants and genes responsible for the survival, regeneration and proliferation of pancreatic $\beta$-cell.
\end{abstract}

\author{
Key Words \\ - islet cells \\ - diabetes \\ - insulin \\ - gene expression \\ - immunohistochemistry
}

Journal of Endocrinology (2014) 220, 291-304

\section{Introduction}

Diabetes mellitus (DM) is a major metabolic disorder and a global health problem currently affecting more than 250 million people worldwide (Zimmet \& Alberti 2006). Type 1 and type 2 DM (T1DM and T2DM) can lead to a number of long-term complications including nephropathy, retinopathy, neuropathy, exocrine glands disorder, foot ulcers and cardiomyopathy (Zimmet \& Alberti 2006). These complications are mainly related to insulin 
deficiency in T1DM or insulin resistance or a combination of both in T2DM, resulting in prolonged hyperglycaemia, hyperlipidaemia and exaggerated levels of reactive oxygen species (ROS) with an impaired antioxidant defence system (D'Souza et al. 2009, Figueroa-Quevedo \& Agil 2011).

Although exogenous insulin is used in T1DM, the majority of T2DM patients can be managed with changes in life style habits and hypoglycaemic drugs (Haan 2006). In addition to these current treatment modalities, other novel ways must also be explored to improve insulin secretion endogenously (Gedulin et al. 2005).

The gastrointestinal (GI) tract plays an important role not only in the digestion and absorption of food but also in the secretion of a number of regulatory hormones. The GI tract is classified as both an endocrine and an exocrine system with much interaction between the two parts (Shetzline \& Liddle 2002). The GI tract secretes a number of hormones including glucose-dependent insulinotropic polypeptide and glucagon-like peptide 1 (GLP1; Drucker 2003b). These endogenous hormones are called incretins because they can elevate the plasma insulin level after a meal. Incretins exert these effects by stimulating insulin release from the $\beta$-cells of the endocrine pancreas as well as potentiating glucose-induced insulin release (Holst 2008). GLP1 is a natural incretin consisting of about 30 amino acids, which is produced by intestinal L-cells in the GI tract, following a meal (Baggio \& Drucker 2007). GLP1 is believed to play a major role in the synthesis and release of insulin in pancreatic $\beta$-cells (Holst 2006, Dorsam \& Gutkind 2007). GLP1 can also suppress the release of glucagon from pancreatic $\alpha$-cells (Holst 2006). Following its release from intestinal cells, GLP1 is quickly destroyed by dipeptidyl peptidase-IV (DPP4; Holst 2007, Lotfy et al. 2011), and with a half-life of just $2 \mathrm{~min}$, GLP1 is not very effective for therapeutically provoking the release of insulin from $\beta$-cells on a long-term basis (Gautier et al. 2008). Thus, newly modified GLP1 analogues have been synthesised to replace GLP1. One such synthetic incretin is exenatide, an artificial form of the natural exendin-4. Exendin-4 was initially extracted from the salivary juice of the lizard, Gila monster (Heloderma suspectum) and was shown to possess about 53\% of the amino acid chain of GLP1 (Baggio \& Drucker 2007). There is much evidence that exenatide can mimic the effect of GLP1, and in addition, it is resistant to DPP4, and thus has a prolonged active half-life compared with GLP1 (Barnett 2007). Previous studies have shown that exenatide can induce anti-apoptotic effect in pancreatic $\beta$-cells and that it possesses GLP1-like effects on the endocrine pancreas. Therefore, this study was designed to investigate the mechanisms by which exenatide exerts its beneficial and protective effects in the rat pancreas during streptozotocin (STZ)-induced T1DM.

\section{Materials and methods}

\section{Animals}

This study employed young male Wistar rats weighing $\sim 250 \mathrm{~g}$. The animals were obtained from the College of Medicine and Health Sciences (CMHS), United Arab Emirates University, breeding colony and the Animal Research Group's guidelines for the care and use of laboratory animals were followed. All rats were housed in temperature- $\left(25^{\circ} \mathrm{C}\right)$ and humidity-controlled rooms with $12 \mathrm{~h}$ light: $12 \mathrm{~h}$ darkness photoperiod cycle. The animals were supplied with a standard rat chow and tap water and allowed to eat and drink ad libitum. This study had ethical clearance from the Ethics Committees of the University of Central Lancashire (UCLAN) and CMHS to carry out the experiments.

\section{Induction of experimental diabetes}

DM was induced in young adult male rats by a single i.p. injection of $(0.3 \mathrm{ml})$ STZ (Sigma) at a dose of $60 \mathrm{mg} / \mathrm{kg}$ body weight (BW) (Adeghate 1999). The STZ was freshly dissolved in citrate buffer $(0.5 \mathrm{M}, \mathrm{pH} 4.5)$. Age-matched healthy control rats received the same volume $(0.3 \mathrm{ml})$ of the citrate buffer only. Five days after injection of either STZ or citrate buffer, the rats were tested for DM using a drop of blood from the tail vein. The estimation of blood glucose level was made using Optium Xceed Glucometer (Abbott Laboratories, Abbott Park, IL, USA) for each rat. The rats were considered diabetic if the fasting blood glucose levels were $\geq 280 \mathrm{mg} / \mathrm{dl}$. Following the diagnosis of DM, agematched healthy control and STZ-induced diabetic rats were divided randomly into four groups each containing ten rats. The diabetic and normal control rats received daily i.p. injections of exenatide, employing a physiological dose $(1 \mu \mathrm{g} / \mathrm{kg} \mathrm{BW})$ for 10 weeks. In addition, two other groups of untreated diabetic and normal control rats received injections of citrated buffer only for the same period. Exenatide was purchased from Phoenix Pharmaceuticals (Burlingame, CA, USA). All measurements except BW and fasting blood glucose levels were performed at the end of the experiment.

Weight measurement The weight of normal and diabetic rats was recorded every 2 weeks using a 9001 Scale (Satorius, Hertfordshire, UK).

Published by Bioscientifica Ltd. 
Fasting blood glucose measurement The fasting blood glucose level was measured every 2 weeks for each individual rat of all groups using samples collected from the tail vein after an overnight fast.

\section{Intraperitoneal glucose tolerance test}

At the end of 10 weeks of treatment, age-matched, healthy controls and STZ-induced diabetic rats were subjected to an intraperitoneal glucose tolerance test (IPGTT), after overnight fasting for $18 \mathrm{~h}$. Each rat from the four groups was given an i.p. glucose load of $2 \mathrm{~g} / \mathrm{kg} \mathrm{BW}$ according to a previously published procedure (Caluwaerts et al. 2007). Blood glucose measurements were made after fasting at zero time (before glucose load), 30, 60, 120 and $180 \mathrm{~min}$ after the glucose load.

\section{Tissue and blood collection and tissue processing}

At the end of the experiments, all ten rats from each group were subjected to general anaesthesia by diethyl ether. Following decapitation, blood was collected in heparinised tubes. The rats were dissected and the pancreas was rapidly removed. Representative pancreatic fragments were taken and used for both morphological, in vitro study and molecular biological investigation.

\section{Biochemical analysis}

Serum levels of aspartate aminotransferase, alanine aminotransferase, creatinine, uric acid cholesterol and serum triglyceride and blood urea nitrogen were determined using the Beckman Coulter Synchron UniCel, DxC, 800 Synchron, Clinical System (Brea, CA, USA).

\section{Serum insulin estimation by ELISA}

Serum insulin level was determined by using a commercial DakoCytomation Kit (Glostrup, Denmark), an ELISA method was based on two MABs. Values were expressed as $\mu \mathrm{IU} / \mathrm{ml}$.

\section{Estimation of in vitro pancreatic insulin release}

The pancreas from each rat in each group was removed and placed in PBS. The in vitro pancreatic insulin release was determined according to a previously described method (Adeghate \& Ponery 2002).

\section{Immunohistochemical studies}

The isolated pancreas from each rat in each group was trimmed free of connective tissues and processed for immunohistochemistry using a previously described method (Adeghate \& Ponery 2004) with antibodies against insulin, glucagon, catalase, glutathione reductase (GSR), GLP1 and exenatide (Table 1). The antibodies for insulin, glucagon, GLP1, exenatide, GSR and catalase were purchased from commercial suppliers. No specific immunostaining was observed in pancreatic tissue sections when primary antibodies were omitted.

\section{Morphometric analysis}

The number of insulin-, glucagon-, GLP1-, exenatide-, glutathione reductase- and catalase-positive cells was counted and estimated semi-quantitatively in treated and untreated normal and diabetic rat pancreatic tissues.

\section{Immunofluorescence studies}

Isolated pancreatic tissues were retrieved, fixed and embedded in paraffin and subsequently processed for double-labelling immunofluorescence using a previously described method (Adeghate \& Ponery 2004) with antibodies against insulin, glucagon, catalase, glutathione reductase, GLP1 and exenatide (Table 1).

\section{Immunoelectron microscopy study}

Nickel grids with sections of pancreatic islets were immersed in $0.01 \mathrm{M}$ sodium citrate buffer at $90^{\circ} \mathrm{C}$ for

Table 1 Antibodies employed in this study

\begin{tabular}{|c|c|c|c|c|c|}
\hline Antibody & Source & Type & Cat no. & Dilution & Manufacturer \\
\hline Anti-insulin & Guinea pig & Polyclonal & A0564 & $1: 1000$ & DakoCytomation \\
\hline Anti-glucagon & Rabbit & Polyclonal & A0565 & $1: 1000$ & DakoCytomation \\
\hline Anti-GLP1 & Rabbit & Polyclonal & $\mathrm{H}-028-13$ & $1: 1000$ & Phoenix Pharmaceuticals \\
\hline Anti-exenatide & Rabbit & Polyclonal & $\mathrm{H}-070-94$ & $1: 1000$ & Phoenix Pharmaceuticals \\
\hline $\begin{array}{l}\text { Anti-glutathione } \\
\text { reductase }\end{array}$ & Mouse & Monoclonal & SAB4200182 & $1: 100$ & Sigma-Aldrich \\
\hline Anti-catalase & Rabbit & Polyclonal & SAB4503383 & $1: 200$ & Sigma-Aldrich \\
\hline
\end{tabular}


$5 \mathrm{~min}$, cooled and jet washed with deionised water. They were later processed for immunoelectron microscopy according to an established method (Mayhew \& Lucocq 2011) using antibodies against either insulin/exenatide or glucagon/exenatide.

\section{Real-time PCR}

Estimation of the levels of gene expression was done using relative quantification (RQ) assay by real-time PCR (RT-PCR) technique (Wong \& Medrano 2005). RQ was used to compare expression levels of genes in pancreatic tissues of treated and untreated rats. Total RNA was extracted from rat pancreatic tissues using a RiboPure Extraction Kit (Ambion-Applied Biosystems, Grand Island, NY, USA) according to the manufacturer's recommendations. cDNA was synthesised using a high-capacity cDNA RT kit with RNAase inhibitor (Applied Biosystems). Gene expression assays using TaqMan labelled primers and probes were undertaken using relative RT-PCR using an Applied Biosystems 7500 RT-PCR System (Applied Biosystems). All primers and TaqMan probes (Table 2) were purchased from Applied Biosystems. PCRs were carried out using the following cycling conditions: as one cycle at $50{ }^{\circ} \mathrm{C}$ for $2 \mathrm{~min}$ then one cycle at $95^{\circ} \mathrm{C}$ for $10 \mathrm{~min}$ followed by 40 cycles at $95^{\circ} \mathrm{C}$ for $15 \mathrm{~s}$ and $60^{\circ} \mathrm{C}$ for $1 \mathrm{~min}$ (Hamouchene et al. 2011). Data were analysed by creating a RQ study using the Sequence Detection Systems (SDS)
Software of a 7500 ABI instrument (Applied Biosystems). The RQ technique was employed to determine the change in the expression of the target gene in the treated sample relative to the untreated sample. The results were calculated as a fold difference of the gene amplification values after their normalisation to the levels of the endogenous $\beta$-actin gene expression.

\section{Statistical analysis}

All values were calculated as mean \pm s.e.M. Student's $t$-test was used to analyse the significance of differences between mean values and different groups were assessed using SPSS Statistical Analysis Software. Differences with $P<0.05$ were accepted as significant when comparing control and treated samples. Differences with either $P<0.01$ or $P<0.001$ were accepted as moderately or highly significant respectively.

\section{Results}

\section{Metabolic parameters}

Figure $1 \mathrm{~A}, \mathrm{~B}$ and $\mathrm{C}$ shows the time courses of changes in body weight (BW), blood glucose level and IPGTT in exenatide-treated $(1 \mu \mathrm{g} / \mathrm{kg} \mathrm{BW})$ and untreated diabetic and age-matched control rats over the 10 weeks of the study. The results show that untreated diabetic rats gained

Table 2 PCR primers (F, forward; R, reverse) and probes (P) used in this study

\begin{tabular}{|c|c|c|c|}
\hline Gene & Species & Reference sequence & Primer and probe sequences \\
\hline $\begin{array}{l}\text { Pancreatic duodenal } \\
\text { homeobox-1 (PDX1) }\end{array}$ & Rat & NM_022852.3 & $\begin{array}{l}\text { F: GGCTTAACCTAAACGCCACA } \\
\text { R: GGGACCGCTCAAGTTTGTAA } \\
\text { P: TGAAAACTTTGAGGCTGCCT }\end{array}$ \\
\hline Heat shock protein-70 (HSP70) & Rat & NM_153629.1 & $\begin{array}{l}\text { F: AGTTGCCCACTGGATTAACG } \\
\text { R: CAAGCAATTGAGACCAGCAA } \\
\text { P: GACTGCCATGCTCTTGTCAA }\end{array}$ \\
\hline Glutathione peroxidase (GPx) & Rat & NM_183403.2 & $\begin{array}{l}\text { F: TGCCCTACCCTTATGACGAC } \\
\text { R: TCGATGTTGATGGTCTGGAA } \\
\text { P: CATTCTCCCTCATGACCGAT }\end{array}$ \\
\hline Glucagon (GCG) & Rat & NM_012707.2 & $\begin{array}{l}\text { F: AACAACATTGCCAAACGTCA } \\
\text { R: CAGCTATGGCGACTTCTTCC } \\
\text { P: TGAATTTGAGAGGCATGCTG }\end{array}$ \\
\hline Insulin receptor (INSr) & Rat & NM_017071.2 & $\begin{array}{l}\text { F: AAAGTTTGCCCAACCATCTG } \\
\text { R: GTGAAGGTCTTGGCAGAAGC } \\
\text { P: TCAGAACCCGATGACCCTAC }\end{array}$ \\
\hline $\begin{array}{l}\text { Glucagon-like peptide } 1 \\
\text { receptor (GLP1r) }\end{array}$ & Rat & NM_012728.1 & $\begin{array}{l}\text { F: ATCCACCTGAACCTGTTTGC } \\
\text { R: GCAGTATTGCATGAGCAGGA } \\
\text { P: GCACTGTCCGTCTTCATCAA }\end{array}$ \\
\hline$\beta$-actin $(A C T B)$ & Rat & NM_031144.2 & $\begin{array}{l}\text { F: AGCCATGTACGTAGCCATCC } \\
\text { R: CTCTCAGCTGTGGTGGTGAA } \\
\text { P: CCACACTGTGCCCATCTATG }\end{array}$ \\
\hline
\end{tabular}



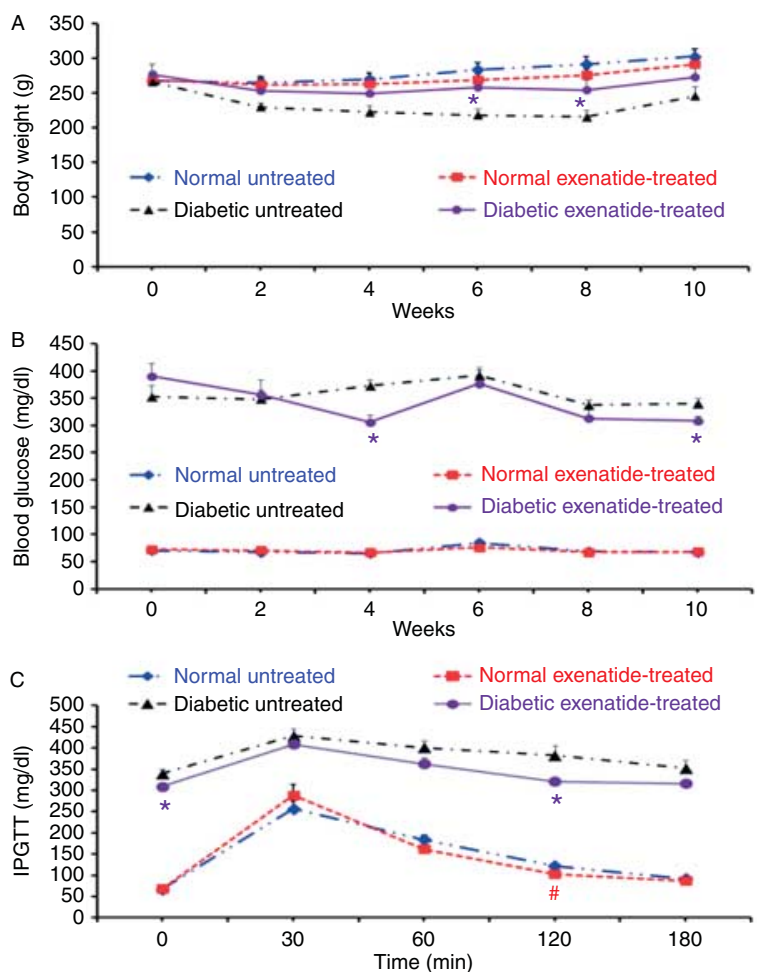

Figure 1

Time course graphs showing the effect of exenatide treatment on (A) body weight, (B) blood glucose levels and (C) intraperitoneal glucose tolerance test (IPGTT) in normal untreated, normal exenatide-treated, untreated diabetic and exenatide-treated diabetic rats. Data are mean \pm s.E.M., $n=10$, ${ }^{*}$ or ${ }^{\#} P<0.05$ for treated compared with untreated rats.

significantly $(P<0.001)$ less weight compared with age-matched normal controls. Treatment of STZ-induced diabetic rats with exenatide $(1 \mu \mathrm{g} / \mathrm{kg}$ BW) resulted in a significant $(P<0.05)$ increase in $\mathrm{BW}$ compared with untreated diabetic rats. Similarly, diabetic rats had significantly $(P<0.05)$ elevated blood glucose levels compared with either control or exenatide-treated age-matched control rats. Treatment of diabetic rats with exenatide resulted in a significant $(P<0.05)$ reduction in blood glucose level at weeks 4 and 8 compared with untreated diabetic rats. In relation to the glucose tolerance test, exenatide-treated control rats had reduced blood glucose level similar to untreated control animals after $60-180 \mathrm{~min}$. Blood glucose was significantly $(P<0.05)$ higher in diabetic treated and untreated rats compared with control untreated and treated animals. However, the blood glucose level in exenatide-treated diabetic rats was significantly lower at $120 \mathrm{~min}$ compared with those of untreated diabetic animals.

\section{Effect of exenatide on insulin release}

Figure $2 \mathrm{~A}$ and $\mathrm{B}$ shows the effect of treating pancreatic fragments with different concentrations $\left(10^{-12}, 10^{-9}\right.$ and $10^{-6} \mathrm{M}$ ) of exenatide on insulin release using samples from age-matched control and diabetic animals after incubation for $1 \mathrm{~h}$ with each concentration of the secretagogue. The results show that exenatide can stimulate insulin release from pancreatic fragments in a dose-dependent manner with significantly $(P<0.001)$ higher release from either control or diabetic fragments compared with basal levels. In addition, insulin release from exenatide-treated control fragments was significantly $(P<0.001)$ higher than that from exenatide-treated diabetic rat pancreas. Similarly, pancreatic fragments of untreated control rats secreted significantly $(P<0.001)$ more insulin compared with those from untreated diabetic animals.

\section{Effect of exenatide on serum insulin level and liver and kidney function}

Table 3 shows the levels of serum insulin, aspartate aminotransferase, alanine aminotransferase, creatinine, uric acid, cholesterol and triglycerides and blood urea nitrogen in normal untreated, normal exenatide-treated, diabetic untreated and diabetic exenatide-treated rats at the end of 10 weeks following treatment. The results show that exenatide treatment can result in a significant $(P<0.05)$ increase in serum insulin compared with untreated control or untreated diabetic rats. In addition, exenatide treatment led to significant $(P<0.05, P<0.01$ or

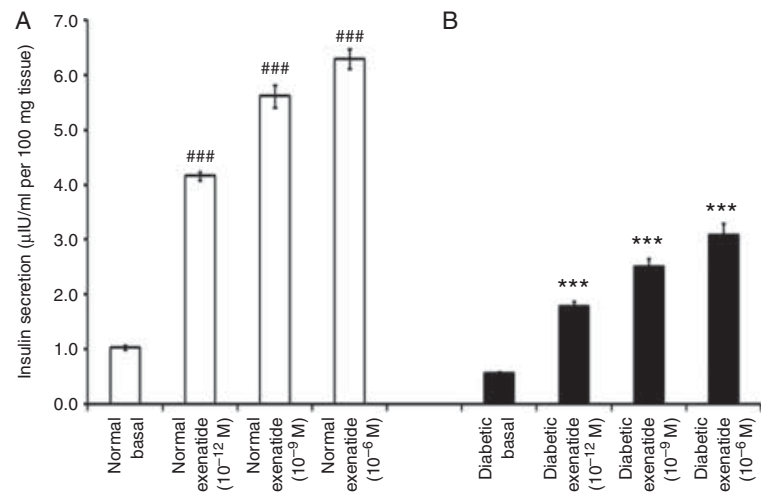

Figure 2

Dose-dependent effects of exenatide on insulin release from (A) normal (control) and (B) untreated diabetic and exenatide-treated rat pancreatic tissue fragments. Pancreatic fragments were incubated with different concentrations of exenatide $\left(10^{-12}, 10^{-9}\right.$ and $\left.10^{-6} \mathrm{M}\right)$ for $1 \mathrm{~h}$ respectively. Data are mean \pm S.E.M., $n=10, * * *$ or ${ }^{\# \# \#} P<0.001$ for control compared with basal levels.

Published by Bioscientifica Ltd 
Table 3 Serum levels of insulin, aspartate and alanine aminotransferases, blood urea nitrogen, serum creatinine, uric acid and serum cholesterol in normal untreated, exenatide-treated normal, untreated diabetic and exenatide-treated diabetic rats

\begin{tabular}{|c|c|c|c|}
\hline Biochemical parameters & Normal untreated & $\begin{array}{c}\text { Normal } \\
\text { exenatide-treated }\end{array}$ & Diabetic untreated \\
\hline $\begin{array}{l}\text { Serum insulin }(\mu \mathrm{IU} / \mathrm{ml}) \\
\text { Serum aspartate } \\
\quad \text { aminotransferase (UI/l) }\end{array}$ & $\begin{array}{l}5.9 \pm 0.3 \\
217 \pm 10.1\end{array}$ & $\begin{array}{r}6.9 \pm 0.3^{\dagger} \\
85 \pm 7.6^{\oplus}\end{array}$ & $\begin{array}{c}3.5 \pm 0.2 \\
444 \pm 23.8\end{array}$ \\
\hline $\begin{array}{l}\text { Serum alanine } \\
\quad \text { aminotransferase }(\mathrm{UI} / \mathrm{l})\end{array}$ & $33 \pm 2.5$ & $22 \pm 2.1^{\S}$ & $192 \pm 22.4$ \\
\hline $\begin{array}{l}\text { Blood urea nitrogen } \\
(\mathrm{mg} / \mathrm{dl})\end{array}$ & $15.8 \pm 1.1$ & $14.9 \pm 1.1$ & $28.7 \pm 1.0$ \\
\hline Serum creatinine $(\mathrm{mg} / \mathrm{dl})$ & $0.45 \pm 0.03$ & $0.35 \pm 0.04^{\dagger}$ & $0.56 \pm 0.04$ \\
\hline Serum uric acid (mg/dl) & $1.4 \pm 0.1$ & $0.92 \pm 0.12^{\dagger}$ & $2.4 \pm 0.36$ \\
\hline Serum cholesterol (mg/dl) & $29 \pm 1.1$ & $23 \pm 2.4^{\dagger}$ & $49 \pm 2.4$ \\
\hline Serum triglyceride $(\mathrm{mg} / \mathrm{dl})$ & $47 \pm 3.6$ & $24 \pm 2.1^{\pi}$ & $79 \pm 6.7$ \\
\hline
\end{tabular}

\begin{tabular}{c}
\hline $\begin{array}{c}\text { Diabetic } \\
\text { exenatide-treated }\end{array}$ \\
\hline $4.7 \pm 0.1^{\ddagger}$ \\
$211 \pm 28.2^{\|}$ \\
$91 \pm 12.7^{\ddagger}$ \\
$25.8 \pm 1.5$ \\
$0.45 \pm 0.02^{*}$ \\
$0.8 \pm 0.15^{\ddagger}$ \\
$44 \pm 5.0$ \\
$48 \pm 5.9^{\ddagger}$
\end{tabular}

* or ${ }^{\dagger} P<0.05$ vs untreated animals, ${ }^{\ddagger}$ or ${ }^{\S} P<0.01$ vs untreated animals and $\|$ or ${ }^{~} P<0.001$ vs untreated animals.

$P<0.001$ ) decreases in serum aspartate aminotransferase, serum alanine aminotransferase, serum creatinine, serum uric acid and serum triglyceride in both control and diabetic rats compared with the respective untreated control and untreated diabetic rats. The results also show that exenatide treatment can cause a small but not significant decrease in serum cholesterol in treated diabetic animals compared with untreated diabetic animals. However, in control animals, exenatide can significantly $(P<0.05)$ reduce serum cholesterol levels compared with those of untreated control rats. In contrast, exenatide has no effect on blood urea nitrogen in either control or diabetic animals compared with the respective untreated control rats.

\section{Effect of exenatide on insulin-, catalase- and glutathione reductase-containing cells}

Figure 3 shows that exenatide treatment had no significant effect on either catalase, glutathione reductase or exenatide-positive cells in the pancreas of exenatide-treated control rats compared with untreated control. However, exenatide treatment resulted in significant $(P<0.05)$ increases in catalase, glutathione reductase and exanatide immunopositive cells in the diabetic rat pancreas compared with those of untreated diabetic animals.

\section{Immunofluorescence double labelling}

Figure 4 shows micrographs of immunofluorescence double labelling of the co-localisation of insulin with exenatide, GLP1, catalase or glutathione reductase in the pancreatic islets of normal and diabetic rats. The results show that insulin is co-localized with exenatide, GLP1, catalase and glutathione reductase in the islet of Langerhans.

Effects of exenatide on the number of insulin-, glucagon-, GLP1-, exenatide-, catalase- and GSR-immunopositive cells in the pancreas of untreated normal, exenatidetreated normal, untreated diabetic and exenatide-treated diabetic rats

Figure 5A, B, C, D, E and F shows the effects of exenatide treatment on the percentage distribution of insulinimmunopositive cells, glucagon-immunopositive cells, GLP1-immunoreactive cells, exenatide-immunoreactive cells, catalase-immunopositive cells and glutathione reductase-immunopositive cells in the pancreas of untreated normal, exenatide-treated normal, untreated diabetic and exenatide-treated diabetic rats, respectively. The results show that exenatide treatment can result in significant $(P<0.05)$ increases in the number of insulin and GLP1-immnopositive cells in the pancreas of both exenatide-treated control and diabetic rats compared with untreated controls. Untreated diabetic rats had significantly $(P<0.05)$ lower numbers of insulin-positive cells and significantly $(P<0.05)$ more GLP1-positive cells compared with control rats. In contrast, exenatide treatment resulted in significant $(P<0.05)$ decreases in the percentage distribution of glucagon-positive cells in both control and diabetic animals. Moreover, the diabetic rats' pancreases had significantly $(P<0.001)$ more glucagon-positive cells compared with those of control animals.

Published by Bioscientifica Ltd 

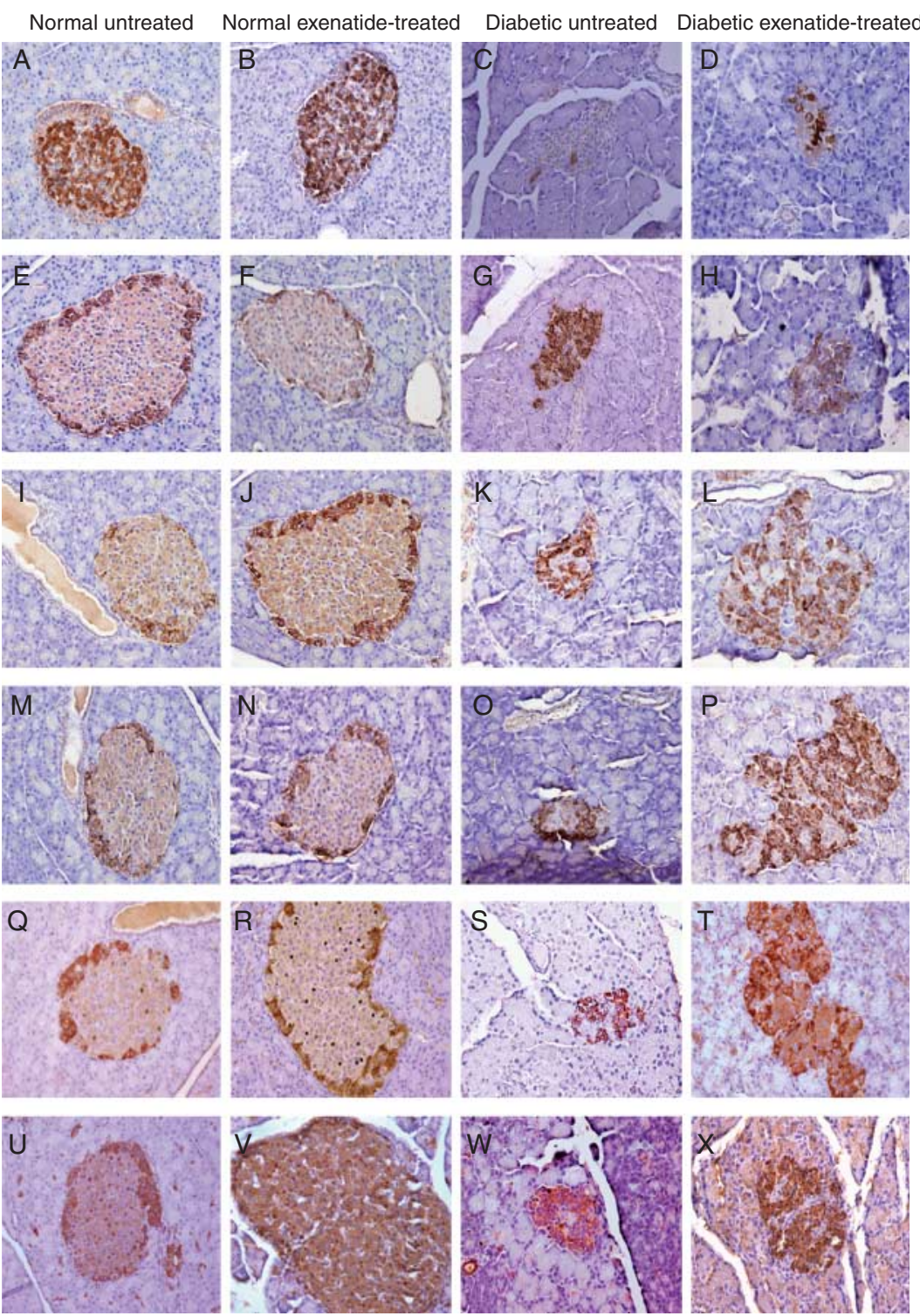

Figure 3

Micrographs showing the effect of exenatide treatment on the distribution of $(A, B, C$ and $D$ ) insulin-, ( $E, F, G$ and $H)$ glucagon-, ( $I, J, K$ and $L)$ exenatide-, $(\mathrm{M}, \mathrm{N}, \mathrm{O}$ and $\mathrm{P})$ GLP1-, $(\mathrm{Q}, \mathrm{R}, \mathrm{S}$ and $\mathrm{T})$ catalase- and $(\mathrm{U}, \mathrm{V}, \mathrm{W}$ and $\mathrm{X})$

glutathione reductase-positive cells. Data are typical of those for ten different animals in each group, $n=10$. Magnification, $\times 400$.

\section{Immunoelectron microscopy}

Immunoelectron microscopy was carried out to visualise the intracellular localization of exenatide and other molecules with which it co-localized. Figure 6 shows immunogold-labelled exenatide in association with insulin- and glucagon-labelled particles in the secretory granules of the pancreatic $\beta$ - and $\alpha$-cells, respectively. The results show that exenatide co-localizes with both insulin and glucagon in the endocrine pancreas.

\section{Effect of exenatide on gene expression of selected molecules}

Figure 7 shows the effects of exenatide treatment on gene expression of (A) pancreatic duodenal homeobox-1, (B) heat shock protein-70 (HSP70), (C) glutathione peroxidase (GPx), (D) glucagon, (E) insulin receptor and (F) GLP1 receptor (GLP1r) in the pancreas of age-matched untreatednormal, exenatide-treated normal, diabetic untreated and exenatide-treated diabetic rats, respectively. The results

Published by Bioscientifica Ltd 

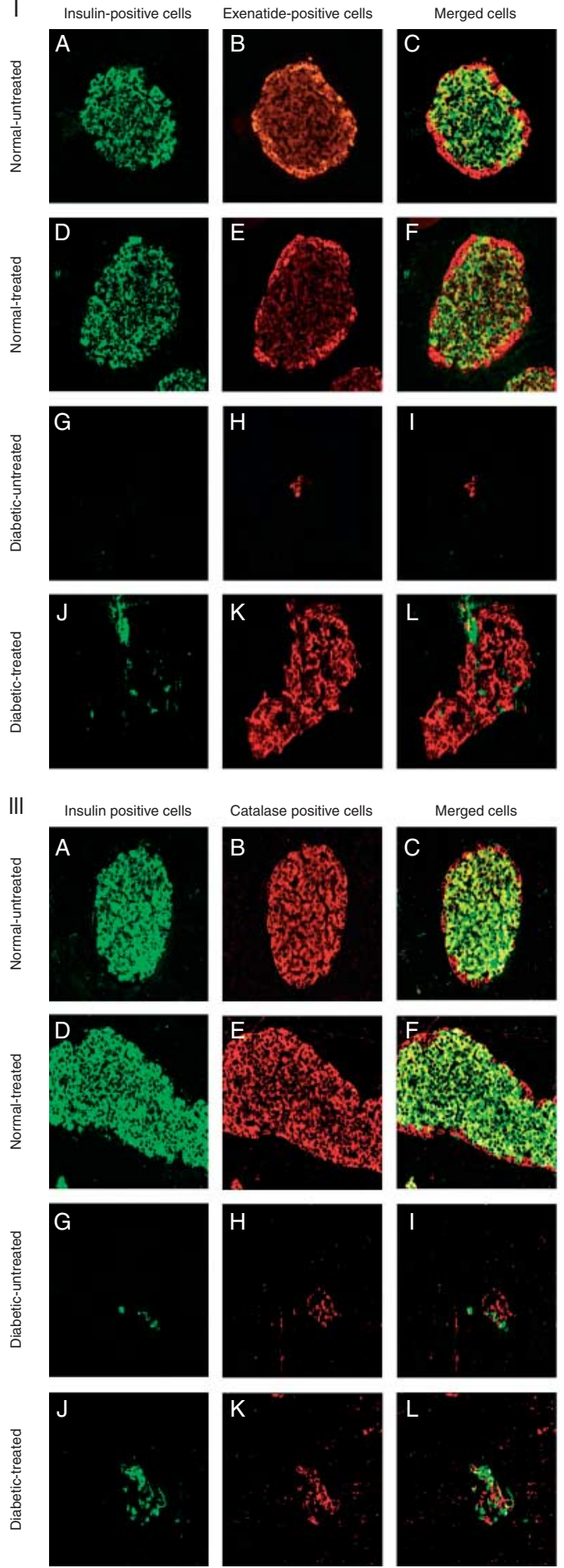
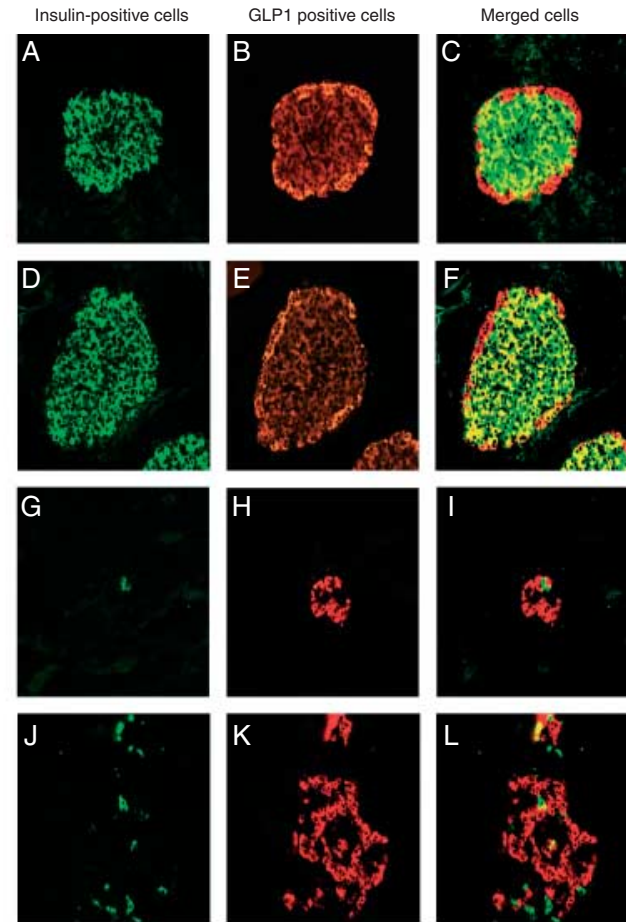

IV Insulin positive cells
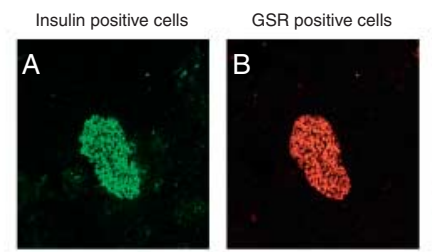

Merged cells
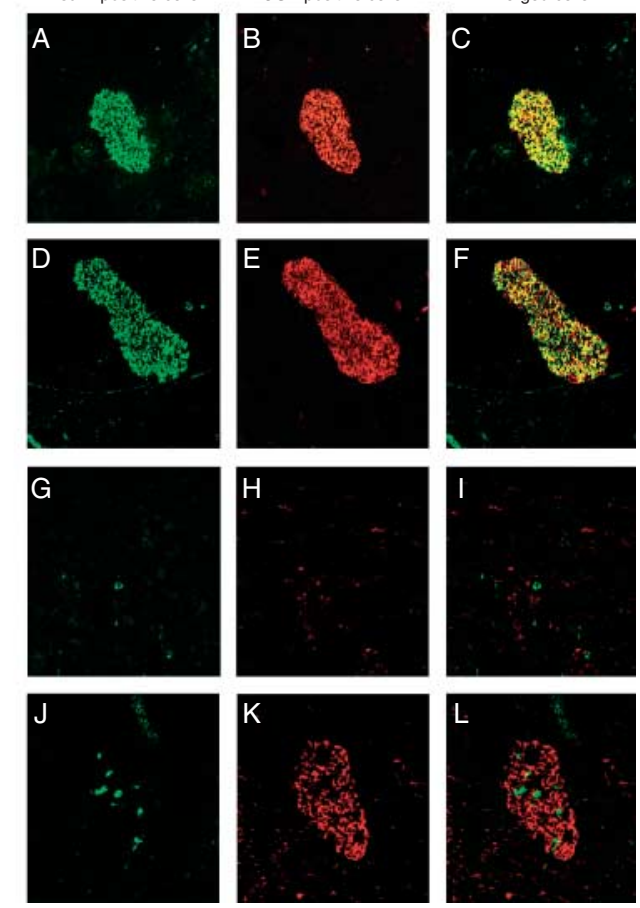

Figure 4

Micrographs of immunofluorescence double labelling showing the distribution of (I) insulin-positive cells (green; A, D, G, J) and exenatidepositive cells (red; $B, E, H, K$ ), (II) insulin-positive cells (green; $A, D, G, J$ ) and GLP1-positive cells (red; B, E, H, K), (III) insulin-positive cells (green; A, D, G, J)

\begin{tabular}{|lr} 
http://joe.endocrinology-journals.org & C 2014 Society for Endocrinology \\
DOI: $10.1530 /$ JOE-13-0426 & Printed in Great Britain
\end{tabular}

and catalase-positive cells (red; $B, E, H, K$ ) and (IV) insulin-positive cells (green; A, D, G, J) and glutathione reductase-positive cells (red; B, E, H, K) in the pancreatic islet of normal and diabetic rats, $n=10$ for each. $(C, F, I, L)$ merged images for groups I-IV. Magnification, $\times 400$. 

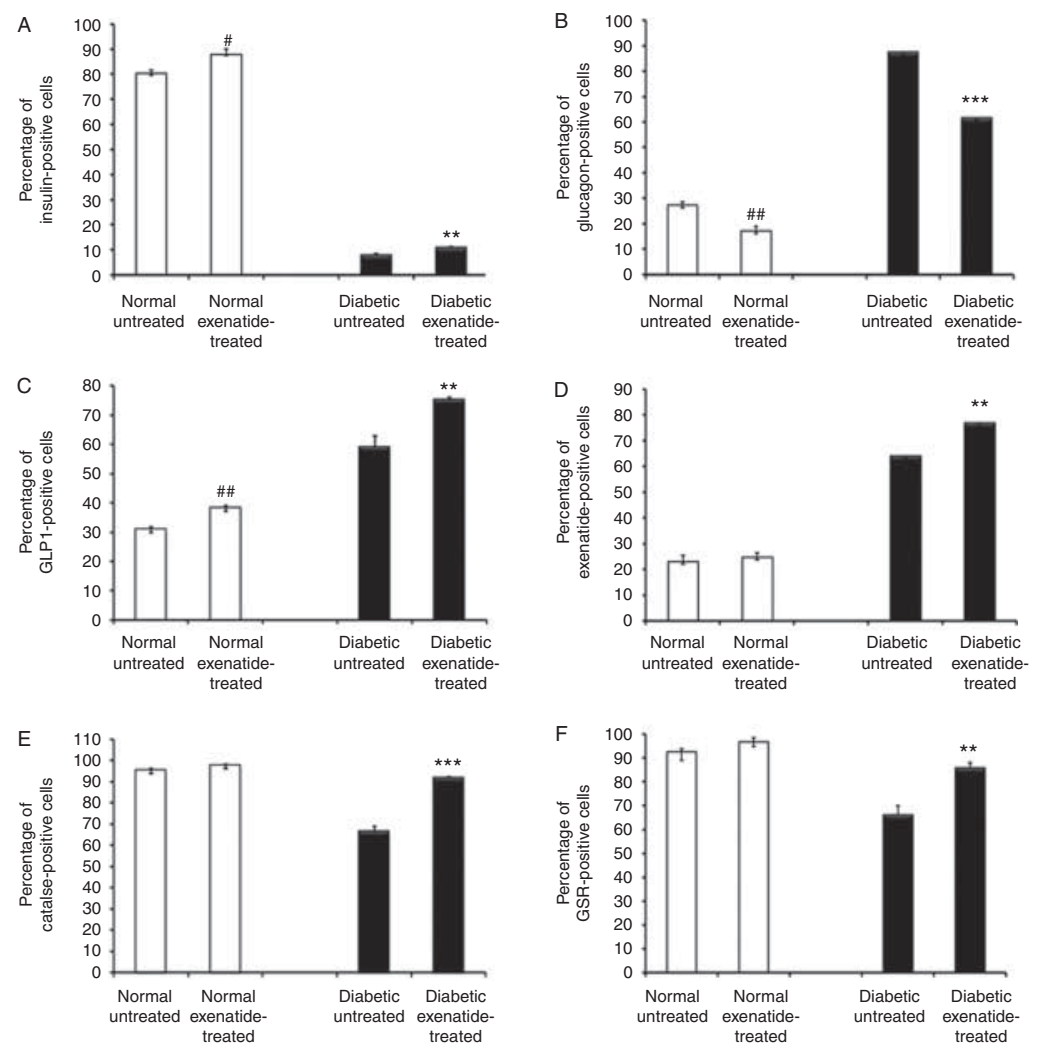

Figure 5

Charts showing the percentage distribution of (A) insulin-, (B) glucagon-, (C) GLP1-, (D) exenatide-, (E) catalase- and (F) glutathione reductase (GSR)-positive cells in the pancreas of normal untreated, normal

reveal that exenatide treatment can induce significant $(P<0.05)$ increases in the gene expression of pancreatic duodenal homeobox-1, HSP70, GPx, insulin receptor and GLP1r in both control and diabetic rats. Moreover, the results further show that exenatide treatment can significantly $(P<0.01)$ reduce glucagon gene expression in both control and diabetic rats compared with untreated animals.

\section{Discussion}

Research into methods that can protect pancreatic $\beta$-cells from damage and help them to produce more endogenous insulin is of paramount importance for the management of DM.

In a normal person, the pancreatic $\beta$-cells mass can adapt itself to different insulin requirements when challenged with various loads of blood glucose. Unfortunately, this process is severely compromised in DM. In T1DM, the $\beta$-cells mass and the cells themselves are either partially or fully damaged leading to a reduced level of insulin secretion. In the case of T2DM, there is a defect

exenatide-treated, untreated diabetic and exenatide-treated diabetic rats. Data are mean \pm S.E.M., $n=10,{ }^{\#} P<0.05,{ }^{*}$ or ${ }^{\# \#} P<0.01$ and $* * * P<0.001$ for treated compared with untreated rats.

in the insulin molecule or the insulin receptor or reduced $\beta$-cell mass (Zimmet \& Alberti 2006). All of these features suggest that the endocrine pancreas is unable to maintain adequate $\beta$-cell mass in DM. This demise of the endocrine pancreas is probably due to a number of environmental insults including life style habits, drugs and genetic factors (Adeghate et al. 2006).

The processes by which the protection, preservation and regeneration of $\beta$-cells can be maintained are of therapeutic importance for the treatment of DM. Recently, a new class of bioactive agents called incretins has been developed. These incretins can increase $\beta$-cells' mass and survival, thus, enhancing their lifespan and optimally regulating the secretion of insulin. Naturally occurring incretin-like substances are located and secreted in the GI tract. These endogenous incretins can stimulate both the synthesis and release of insulin from pancreatic $\beta$-cells (Cernea \& Raz 2011). One such substance is the naturally occurring hormone, GLP1. Unfortunately, GLP1 has a very short half-life leading to its early degradation (Lotfy et al. 2011). However, its synthetic analogue, exenatide has

Published by Bioscientifica Ltd. 

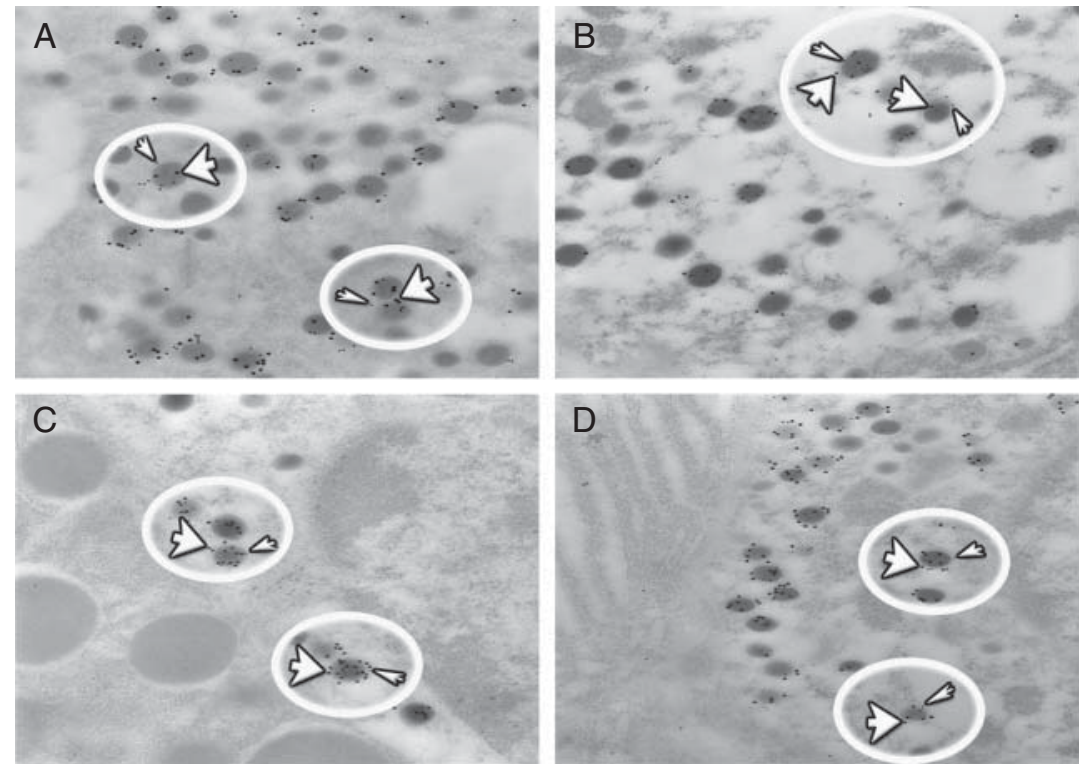

\section{Figure 6}

Electron micrographs showing immunogold labelling of pancreatic cells. Images showing $\beta$-cells in (A) normal and (B) diabetic rats. Large arrows show insulin granules ( $20 \mathrm{~nm}$ gold particles) and small arrows show exenatide ( $15 \mathrm{~nm}$ gold particles). Images showing $\alpha$-cells of pancreatic islets in (C) normal and (D) diabetic rats. Large arrows show glucagon granules

been shown to have a greater potential than natural GLP1 in inducing the pancreas to synthesise and produce insulin (Dungan \& Buse 2005). Exenatide is the synthetic form of exendin-4, a naturally occurring peptide consisting of 39 amino acids and which was isolated from the salivary fluid of the lizard, H. suspectum or Gila monster (Baggio \& Drucker 2007). Generally, exenatide shows a similar structure to that of human GLP1, with a similarity of $53 \%$ for the amino acid sequence (Kim \& Egan 2008). Exenatide is described as an incretin mimetic polypeptide, which can activate GLP1r in pancreatic $\beta$-cell membrane (Holst 2007). The GLP1r is a G-protein-coupled receptor spanning the $\beta$-cell plasma membrane (Brubaker $\&$ Drucker 2002). One major difference between GLP1 and exenatide is the type of amino acid, which is found in position two of the molecule. GLP1 has alanine whereas exenatide has glycine. The presence of glycine makes exenatide unrecognisable by the enzyme DPP4, which is responsible for its slow degradation, thus prolonging its plasma half-life (Lotfy et al. 2011).

\section{Effect of exenatide on metabolic parameters}

The results of this study have demonstrated that administration of exenatide at a physiological dose to
( $20 \mathrm{~nm}$ gold particles) and small arrows show exenatide ( $15 \mathrm{~nm}$ gold particles). The results show that exenatide is co-localised with both insulin and glucagon in the endocrine pancreas, where they lie side by side in secretory granules, $n=10$ for each. Magnification, $\times 27500$.

STZ-induced diabetic rats can produce both protective and beneficial effects on the animals compared with untreated diabetic rats. Similarly, exenatide exerts the same protective and beneficial effects in treated control rats compared with untreated animals. Following treatment with exenatide, the diabetic rats gained significantly more weight and moreover, they had significantly less blood glucose compared with untreated diabetic animals. Exenatide reduces weight gain in obese patients, which is beneficial to the overall management of DM patients with obesity (Vilsbøll et al. 2012). In this study, we observed that diabetic rats treated with exenatide gained weight throughout the experimental period. The weight gain may be due to the fact that exenatide improves $\beta$-cell mass and insulin release. Exenatide treatment resulted in marked and significant elevation of insulin release from both control and diabetic rat pancreas compared with the results for untreated animals. It is worth noting that exenatide was more effective in inducing insulin release from the control rat pancreas compared with that from the diabetic rat pancreas. These studies also show that exenatide acts as a powerful secretagogue to induce insulin release from the pancreas. In addition, the present results have clearly demonstrated that exenatide treatment can lead to an upregulation of gene expressions for GLP1 and

Published by Bioscientifica Ltd. 

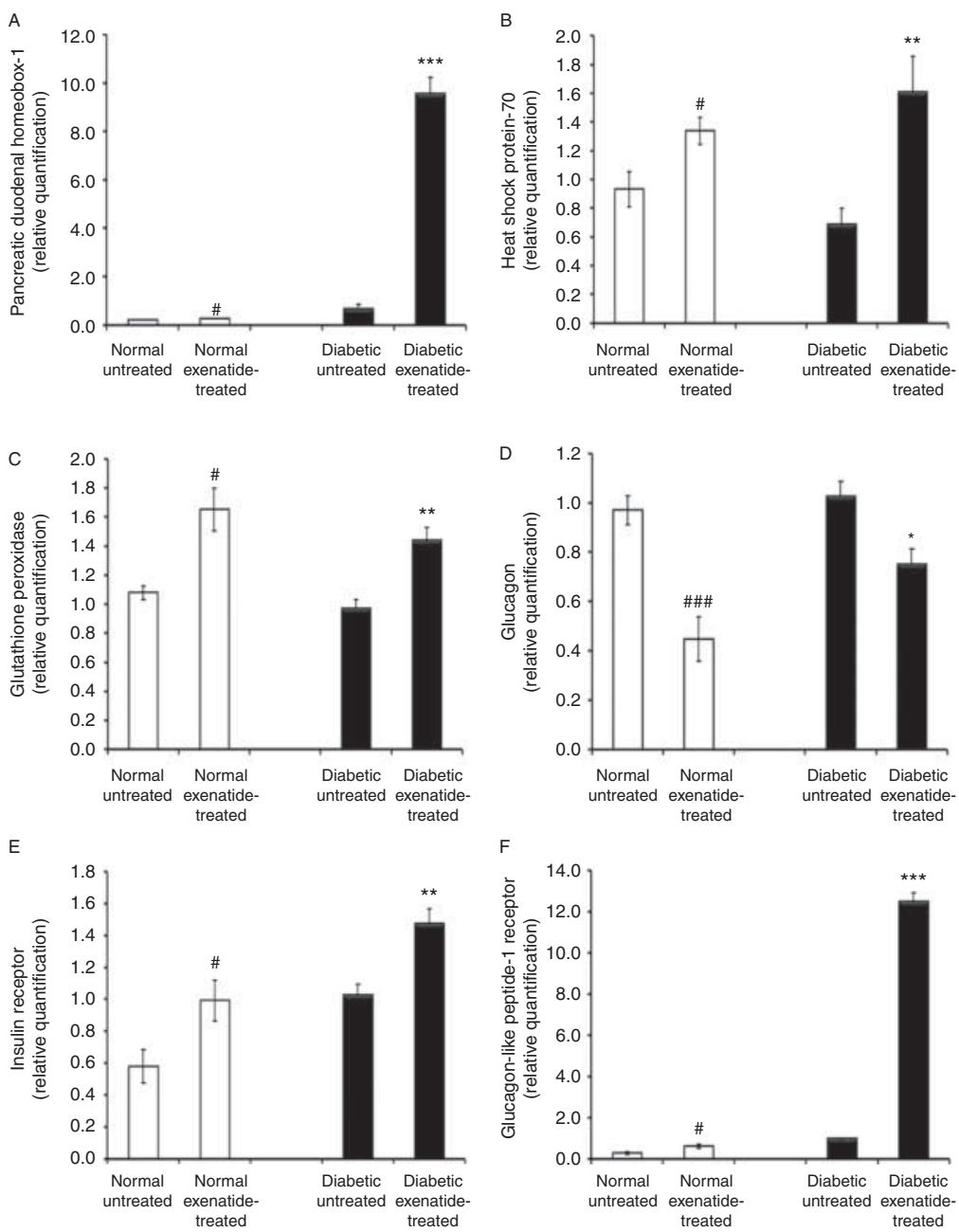

\section{Figure 7}

Charts showing the effect of exenatide treatment on the gene expressions, expressed as relative quantifications, of (A) pancreatic duodenal homeobox-1, (B) heat shock protein-70, (C) glutathione peroxidase, (D) glucagon, $(E)$ insulin receptors and (F) glucagon-like peptide-1 receptor (GLP1r) in the

insulin receptors, as well as pancreatic duodenal homeobox-1 in both the treated control and treated diabetic rats compared with the respective untreated controls. Similarly, exenatide treatment can result in the elevation of the number of exenatide-, insulin- and GLP1-immunopositive cells in both control and diabetic rat pancreas compared with the levels in untreated rats.

The question which now arises is how does exenatide exert its beneficial effect on the endocrine pancreas? Exenatide is believed to exert its beneficial effect in the endocrine pancreas by maintaining optimal $\beta$-cell mass and function by increasing the $\beta$-cell gene expression. In turn, this may lead to $\beta$-cell proliferation and neogenesis, thereby inhibiting apoptosis in pancreatic islet cells (Xu et al. 2009). Exenatide can also exert its secretagogue effect on insulin Printed in Great Britain pancreas of age-matched normal untreated, normal exenatide-treated, untreated diabetic and exenatide-treated diabetic rats. Data are mean \pm s.E.M., $n=10,{ }^{*}$ or ${ }^{\#} P<0.05,{ }^{*} P<0.01$ and ${ }^{* *}$ or ${ }^{\# \# \#} P<0.001$ for treated compared with untreated animals.

release by activating GLP1r in the $\beta$-cells. In addition, it was previously demonstrated that exenatide can elicit a short-term effect on pancreatic $\beta$-cell responsiveness to glucose, resulting in the release of insulin when the body is subjected to hyperglycaemia. In turn, this will subsequently lead to a concomitant reduction in both blood glucose and insulin release (Barnett 2007).

\section{Exenatide and liver and kidney functions}

In addition to the release of insulin from $\beta$-cells, the present results have also indicated that exenatide treatment can protect the diabetic rats from both kidney dysfunction and liver damage compared with untreated diabetic rats. Our result corroborates those of

Published by Bioscientifica Ltd. 
Vaghasiya et al. (2010). In exenatide-treated diabetic rats, there were significant decreases in serum levels of alanine and aspartic aminotransferases, cholesterol, triglyceride, uric acids, blood urea nitrogen and creatinine compared with untreated diabetic rats.

\section{Effect of exenatide on endogenous antioxidants}

Treatment of diabetic rats with exenatide can result in significant increases in the number of catalase- and glutathione reductase-positive cells and the gene expressions of GPX and HSP70 compared with untreated diabetic animals. These results clearly show that exenatide can exert a protective effect on rats, especially in the pancreas by enhancing the levels of markers and mediators that prevent the generation of ROS. The antioxidative defence mechanisms in the pancreatic $\beta$-cells are potentially weak in DM and in turn, these can be overwhelmed by redox imbalance arising from overproduction of ROS and reactive nitrogen species (Lenzen 2008). This imbalance is exacerbated further during DM. Consequences of this redox imbalance are lipid peroxidation, increased oxidative-specific proteins, DNA damage and interference of ROS with signalling pathways, all of which contribute to $\beta$-cells damage, dysfunction and subsequent death, especially during DM (Deavall et al. 2012). ROS, superoxide radicals and hydrogen peroxide are all produced during pro-inflammatory $\beta$-cell attack and glycolipid-toxicity-mediated $\beta$-cell dysfunction ( $\mathrm{Li}$ et al. 2008). In combination with nitric oxide accumulation, these processes lead to the generation of more ROS resulting in pancreatic $\beta$-cell death (Amin et al. 2011).

\section{Effect of exenatide on gene expression of selected molecules}

Exenatide treatment provides protection for pancreatic $\beta$-cells during DM via elevations in the synthesis and gene expression of catalase and GPx, naturally occurring antioxidant proteins, which protect pancreatic $\beta$-cells from oxidative stress (Teixeira-Lemos et al. 2011). The beneficial effect of GPx not only targets oxidative stress but also reduces glucotoxicity by enhancing glucose tolerance. This process preserves $\beta$-cell morphology and function (Robertson \& Harmon 2007).

Similarly, exenatide induced the elevation of HSP70 in diabetic rat pancreas. This protein plays a major role in reducing cell death and prolonging cell survival by stabilising denatured proteins, thereby eliminating damaged proteins for degradation or by interfering with the apoptotic process in $\beta$-cells (Muranyi et al. 2005). It is well-known that HSP70 levels are suppressed in DM, especially during insulin deficiency. As exenatide can induce insulin synthesis and release, this insulin in turn may directly elicit the expression of HSP70 leading to the protection of $\beta$-cells (Chen et al. 2006).

The results of this study also showed significant reduction in the expression of the glucagon gene in the pancreas of normal and diabetic rats treated with pharmacological doses of exenatide. Exenatide may inhibit glucagon expression and release from $\alpha$-cells via GLP1 $r$ found on the plasma membrane of $\alpha$-cells (Heller et al. 1997). This may in turn result in increased GLP1 synthesis from the $\alpha$-cells as observed in the mouse pancreas (Kedees et al. 2009). The increased release of GLP1 can in turn stimulate insulin secretion from pancreatic $\beta$-cells (Nie et al. 2000).

A significant hike in the expression of the insulin receptor gene was also observed in the pancreases of normal and diabetic rats treated with exenatide. Signal transduction via insulin receptors on $\beta$-cells regulates the production, secretion and response of insulin to food (Fisher \& White 2004, Nandi et al. 2004). Therefore, an increase in insulin receptor expression in the pancreatic $\beta$-cells is of paramount importance in the treatment of DM. The results of this study corroborate those of Park et al. (2006), who showed that exenatide uses insulin receptors to promote $\beta$-cell survival.

PDX1 is known to play an important role in the development and maturation of the pancreas and in the maintenance of normal $\beta$-cell function (Kaneto et al. 2007). In an earlier study, a significant regulatory function of the PDX1 transcription factor on the effect of GLP1r in the mouse pancreatic $\beta$-cell was presented. This report shows that exenatide can significantly enhance growth, insulin mRNA expression and insulin release in pancreatic $\beta$-cells in addition to its ability to inhibit apoptosis. In spite of these advantages, exenatide was unable to increase insulin secretion in pancreatic $\beta$-cells of $P d x 1$ knockout mice (Li et al. 2005). Another similar study has shown that stimulation of GLP1r signalling improves insulin gene expression (Fontes et al. 2010). Exenatide may be able to enhance $\beta$-cell transcription factor PDX1 through depression of glucolipotoxicity (McCarty 2007). The effect of exenatide on pancreatic $\beta$-cell differentiation after PDX1 stimulation may occur via protein kinase B and cAMP-dependent mechanisms (Drucker 2003a, Holz 2004). Moreover, exenatide may initiate its action on pancreatic $\beta$-cells via the stimulation of PI3K/PKB, a cell

Published by Bioscientifica Ltd. 
protecting system, and/or through the suppression of the caspase-3 apoptotic pathway (Vaghasiya et al. 2010).

Signal transduction via GLP1R plays an important role in the regulation of pancreatic $\beta$-cell differentiation and extending its lifespan. It is possible that exenatide exerts its effect via GLP1R-induced pathways. In fact, it has been shown that pancreatic islet cells failed to proliferate when $\mathrm{GLP}^{-1-}$ mice were treated with exenatide (Deleon et al. 2003). Moreover, propagation of cell signalling and proliferation was observed when GLP1 bound to receptors on the plasma membrane of pancreatic progenitor cells (Suen et al. 2008). GLP1 is believed to act via cAMP and a PI3K-dependent system leading to an increase in $\beta$-cell mass (Salehi et al. 2008).

\section{Co-localisation of exenatide with insulin}

As this study shows that exenatide is co-localised with insulin in the secretory granules of the endocrine pancreas, it may also regulate insulin metabolism at the cellular level, a molecular explanation for the protective and beneficial effect of incretins in DM. Co-localisation of GLP1 with neuropeptide PYY was recently reported in L-cells (Habib et al. 2013).

In conclusion, the results of this study have clearly demonstrated that the GLP1 analogue, exenatide can exert marked protective and beneficial effects on the endocrine pancreas of the diabetic rats, culminating in an optimal and efficient synthesis and release of insulin. This is done via a myriad of cellular and molecular pathways.

\section{Declaration of interest}

The authors declare that there is no conflict of interest that could be perceived as prejudicing the impartiality of the research reported.

\section{Funding}

This research was supported by grant from the United Arab Emirates University.

\section{Author contribution statement}

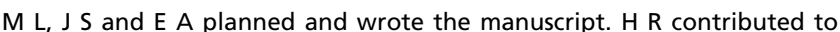
the experimental data. S T contributed to the electron microscopy, $\mathrm{E} Z \mathrm{Z}$ contributed to the gene expression studies.

\section{References}

Adeghate E 1999 Effect of subcutaneous pancreatic tissue transplants on streptozotocin-induced diabetes in rats. I. Morphological studies on

http://joe.endocrinology-journals.org DOI: $10.1530 / J O E-13-0426$
(C) 2014 Society for Endocrinology Printed in Great Britain normal, diabetic and transplanted pancreatic tissues. Tissue \& Cell $\mathbf{3 1}$ 66-72. (doi:10.1054/tice.1999.0008)

Adeghate E \& Ponery AS 2002 Ghrelin stimulates insulin secretion from the pancreas of normal and diabetic rats. Journal of Neuroendocrinology 14 555-560. (doi:10.1046/j.1365-2826.2002.00811.x)

Adeghate E \& Ponery AS 2004 Diabetes mellitus influences the degree of co-localization of calcitonin-gene-related-peptide with insulin and somatostatin in the rat pancreas. Pancreas 29 311-319. (doi:10.1097/ 00006676-200411000-00011)

Adeghate E, Schattner P \& Dunn E 2006 An update on the etiology and epidemiology of diabetes mellitus. Annals of the New York Academy of Sciences 1084 1-29. (doi:10.1196/annals.1372.029)

Amin A, Lotfy M, Mahmoud-Ghoneim D, Adeghate E, Al-Akhras MA, Al-Saadi M, Al-Rahmoun S \& Hameed R 2011 Pancreas-protective effects of chlorella in STZ-induced diabetic animal model: insights into the mechanism. Journal of Diabetes Mellitus 3 36-45. (doi:10.4236/ jdm.2011.13006)

Baggio LL \& Drucker DJ 2007 Biology of incretins: GLP-1 and GIP. Gastroenterology 132 2131-2157. (doi:10.1053/j.gastro.2007.03.054)

Barnett A 2007 Exenatide. Expert Opinion on Pharmacotherapy 8 2593-2608. (doi:10.1517/14656566.8.15.2593)

Brubaker PL \& Drucker DJ 2002 Structure-function of the glucagon receptor family of $\mathrm{G}$ protein-coupled receptors: the glucagon, GIP, GLP-1, and GLP-2 receptors. Receptors \& Channels 8 179-188. (doi:10.1080/10606820213687)

Caluwaerts S, Lambin S, van-Bree R, Peeters H, Vergote I \& Verhaeghe J 2007 Diet-induced obesity in gravid rats engenders early hyperadiposity in the offspring. Metabolism 56 1431-1438. (doi:10.1016/ j.metabol.2007.06.007)

Cernea S \& Raz I 2011 Therapy in the early stage: incretins. Diabetes Care 34 S264-S271. (doi:10.2337/dc11-s223)

Chen HS, Jia J, Su HF, Lin HD, Chen JW, Lin SJ, Yang JY, Lai HC, Mestril R \& Wang PH 2006 Down regulation of the constitutively expressed Hsc70 in diabetic myocardium is mediated by insulin deficiency. Journal of Endocrinology 190 433-440. (doi:10.1677/joe.1.06692)

Deavall DG, Martin EA, Horner JM \& Roberts R 2012 Drug-induced oxidative stress and toxicity. Journal of Toxicology 2012645460. (doi:10.1155/2012/645460)

Deleon DD, Deng S, Madani R, Ahima RS, Drucker DJ \& Stoffers DA 2003 Role of endogenous glucagons-like peptide- 1 in islet regeneration after partial pancreatectomy. Diabetes 52 365-371. (doi:10.2337/ diabetes.52.2.365)

Dorsam RT \& Gutkind JS 2007 G-protein-coupled receptors and cancer. Nature Reviews. Cancer 7 79-94. (doi:10.1038/nrc2069)

Drucker DJ $2003 a$ Glucagon-like peptide- 1 and the islet $\beta$-cell: augmentation of cell proliferation and inhibition of apoptosis. Journal of Endocrinology 144 5145-5148. (doi:10.1210/en.2003-1147)

Drucker DJ $2003 b$ Enhancing incretin action for the treatment of type 2 diabetes. Diabetes Care 26 2929-2940. (doi:10.2337/diacare.26.10.2929)

D'Souza A, Hussain M, Howarth FC, Woods NM, Bidasee K \& Singh J 2009 Pathogenesis and pathophysiology of accelerated atherosclerosis in the diabetic heart. Molecular and Cellular Biochemistry 331 89-116. (doi:10.1007/s11010-009-0148-8)

Dungan K \& Buse JB 2005 Glucagon-like peptide 1-based therapies for type 2 diabetes: a focus on exenatide. Clinical Diabetes 23 56-62. (doi:10.2337/diaclin.23.2.56)

Figueroa-Quevedo A \& Agil A 2011 Changes in plasma's oxidative stress and antioxidant activity, measured with melatonin levels, and its relationship to newborns from obese and diabetic pregnancies. Journal of Diabetes \& Metabolism S4 002. (doi:10.4172/2155-6156. S4-002)

Fisher TL \& White MF 2004 Signaling pathways: the benefits of good communication. Current Biology 14 R1005-R1007. (doi:10.1016/ j.cub.2004.11.024)

Fontes G, Hagman DK, Latour MG \& Semache M 2010 Lack of preservation of insulin gene expression by a glucagon-like peptide 1 agonist or a 
dipeptidyl peptidase 4 inhibitor in an in vivo model of glucolipotoxicity. Diabetes Research and Clinical Practice 87 322-328. (doi:10.1016/j.diabres.2009.12.020)

Gautier JF, Choukem SP \& Girard J 2008 Physiology of incretins (GIP and GLP-1) and abnormalities in type 2 diabetes. Diabetes \& Metabolism 34 S65-S72. (doi:10.1016/S1262-3636(08)73397-4)

Gedulin BR, Nikoulina SE, Smith PA, Gedulin G, Nielsen LL, Baron AD, Parkes DG \& Young AA 2005 Exenatide (exendin-4) improves insulin sensitivity and $\beta$-cell mass in insulin-resistant obese $\mathrm{fa} / \mathrm{fa}$ Zucker rats independent of glycemia and body weight. Journal of Endocrinology 146 2069-2076. (doi:10.1210/en.2004-1349)

Haan MN 2006 Therapy insight: type 2 diabetes mellitus and the risk of late-onset Alzheimer's disease. Nature Clinical Practice. Neurology 2 159-166. (doi:10.1038/ncpneuro0124)

Habib AM, Richards P, Rogers GJ, Reimann F \& Gribble FM 2013 Co-localisation and secretion of glucagon-like peptide 1 and peptide YY from primary cultured human L cells. Diabetologia 56 1413-1416. (doi:10.1007/s00125-013-2887-z)

Hamouchene H, Arlt VM, Giddings I \& Phillips DH 2011 Influence of cell cycle on responses of MCF-7 cells to benzo[a]pyrene. BioMed Central Genomics 12 333. (doi:10.1186/1471-2164-12-333)

Heller RS, Kieffer TJ \& Habener JF 1997 Insulinotropic glucagon-like peptide I receptor expression in glucagon-producing $\alpha$-cells of the rat endocrine pancreas. Diabetes 46 785-791. (doi:10.2337/diab.46.5.785)

Holst JJ 2006 Glucagon-like peptide-1: from extract to agent. The Claude Bernard lecture. Diabetologia 49 253-260. (doi:10.1007/s00125-0050107-1)

Holst JJ 2007 The physiology of glucagon-like peptide 1. Physiological Reviews 87 1409-1439. (doi:10.1152/physrev.00034.2006)

Holst JJ 2008 The physiology and pharmacology of incretins in type 2 diabetes mellitus. Diabetes, Obesity \& Metabolism 10 14-21. (doi:10.1111/j.1463-1326.2008.00920.x)

Holz GG 2004 Epac: a new cAMP-binding protein in support of glucagonlike peptide- 1 receptor-mediated signal transduction in the pancreatic $\beta$-cell. Diabetes 53 5-13. (doi:10.2337/diabetes.53.1.5)

Kaneto H, Miyatsuka T, Fujitani Y, Noguchi H, Song KH, Yoon HK \& Matsuoka TA 2007 Role of PDX-1 and MafA as a potential therapeutic target for diabetes. Diabetes Research and Clinical Practice 77 S127-S137. (doi:10.1016/j.diabres.2007.01.046)

Kedees MH, Grigoryan M, Guz Y \& Teitelman G 2009 Differential expression of glucagon and glucagon-like peptide 1 receptors in mouse pancreatic $\alpha$ and $\beta$ cells in two models of $\alpha$ cell hyperplasia. Molecular and Cellular Endocrinology 311 69-76. (doi:10.1016/j.mce.2009.07.024)

Kim W \& Egan JM 2008 The role of incretins in glucose homeostasis and diabetes treatment. Pharmacological Reviews 60 470-512. (doi:10.1124/ pr.108.000604)

Lenzen S 2008 Oxidative stress: the vulnerable $\beta$-cell. Biochemical Society Transactions 36 343-347. (doi:10.1042/BST0360343)

Li Y, Cao X, Li L-X, Brubaker PL, Edlund H \& Drucker DJ $2005 \beta$-Cell Pdx 1 expression is essential for the glucoregulatory, proliferative, and cytoprotective actions of glucagon-like peptide-1. Diabetes $\mathbf{5 4} 482-491$. (doi:10.2337/diabetes.54.2.482)

Li N, Frigerio F \& Maechler P 2008 The sensitivity of pancreatic $\beta$-cells to mitochondrial injuries triggered by lipotoxicity and oxidative stress. Biochemical Society Transactions 36 930-934. (doi:10.1042/BST0360930)

Lotfy M, Singh J, Kalász H, Tekes K \& Adeghate E 2011 Medicinal chemistry and applications of incretins and DPP-4 inhibitors in the treatment of type 2 diabetes mellitus. Open Medicinal Chemistry Journal 5 82-92. (doi:10.2174/1874104501105010082)
Mayhew TM \& Lucocq JM 2011 Multiple-labelling immunoEM using different sizes of colloidal gold: alternative approaches to test for differential distribution and colocalization in subcellular structures. Histochemistry and Cell Biology 135 317-326. (doi:10.1007/s00418-0110788-0)

McCarty MF 2007 Exenatide and biotin in conjunction with a proteinsparing fast for normalization of $\beta$ cell function in type 2 diabetics. Medical Hypotheses 69 928-932. (doi:10.1016/j.mehy.2005.09.059)

Muranyi M, Hea QP, Fongc KSK \& Li P 2005 Induction of heat shock proteins by hyperglycemic cerebral ischemia. Brain Research. Molecular Brain Research 139 80-87. (doi:10.1016/j.molbrainres.2005.05.023)

Nandi A, Kitamura Y, Kahn CR \& Accili D 2004 Mouse models of insulin resistance. Physiological Reviews 84 623-647. (doi:10.1152/physrev. 00032.2003)

Nie Y, Nakashima M, Brubaker PL, Li Q-L, Perfetti R, Jansen E, Zambre Y, Pipeleers D \& Friedman TC 2000 Regulation of pancreatic PC1 and PC2 associated with increased glucagon-like peptide 1 in diabetic rats. Journal of Clinical Investigation 105 955-965. (doi:10.1172/JCI7456)

Park S, Dong X, Fisher TL, Dunn S, Omer AK, Weir G \& White MF 2006 Exendin- 4 uses Irs2 signaling to mediate pancreatic $\beta$ cell growth and function. Journal of Biological Chemistry 281 1159-1168. (doi:10.1074/ jbc.M508307200)

Robertson RP \& Harmon JS 2007 Pancreatic islet $\beta$-cell and oxidative stress: the importance of glutathione peroxidase. FEBS Letters $\mathbf{5 8 1} 3743-3748$. (doi:10.1016/j.febslet.2007.03.087)

Salehi M, Aulinger BA \& D'Alessio DA 2008 Targeting $\beta$-cell mass in type 2 diabetes: promise and limitations of new drugs based on incretins. Endocrine Reviews 29 367-379. (doi:10.1210/er.2007-0031)

Shetzline MA \& Liddle RA 2002 Gastrointestinal hormones and neurotransmitters. In Sleisenger and Fordtran's Gastrointestinal and Liver Disease: Pathophysiology, Diagnosis, Management, 7th edn, pp 3-20. Eds M Feldman, MH Sleisenger \& LS Friedman. Philadelphia: W B Saunders.

Suen PM, Zou C, Zhang YA, Lau TK, Chan J, Yao KM \& Leung PS 2008 PDZ-domain containing-2 (PDZD2) is a novel factor that affects the growth and differentiation of human fetal pancreatic progenitor cells. International Journal of Biochemistry \& Cell Biology 40 789-803. (doi:10.1016/j.biocel.2007.10.020)

Teixeira-Lemos E, Nunes S, Teixeira F \& Reis F 2011 Regular physical exercise training assists in preventing type 2 diabetes development: focus on its antioxidant and anti-inflammatory properties. Cardiovascular Diabetology 10 12. (doi:10.1186/1475-2840-10-12)

Vaghasiya JD, Sheth NR, Bhalodia YS \& Jivani NP 2010 Exaggerated liver injury induced by renal ischemia reperfusion in diabetes: effect of exenatide. Saudi Journal of Gastroenterology 16 174-180. (doi:10.4103/ 1319-3767.65187)

Vilsbøll T, Christensen M, Junker AE, Knop FK \& Gluud LL 2012 Effects of glucagon-like peptide-1 receptor agonists on weight loss: systematic review and meta-analyses of randomised controlled trials. BMJ 344 d7771. (doi:10.1136/bmj.d7771)

Wong ML \& Medrano JF 2005 Real-time PCR for mRNA quantitation. BioTechniques 39 75-85. (doi:10.2144/05391RV01)

Xu Y, Wei Z, Zhang Z, Xing Q, Hu P, Zhang X, Gao G, Wang Y, Gao Q, Yi L et al. 2009 No association of the insulin gene VNTR polymorphism with polycystic ovary syndrome in a Han Chinese population. Reproductive Biology and Endocrinology 7 1-5. (doi:10.1186/1477-7827-7-141)

Zimmet PZ \& Alberti KG 2006 Globalisation and the non-communicable disease epidemic. Obesity 14 1-3. (doi:10.1038/oby.2006.1)

Received in final form 22 November 2013

Accepted 16 December 2013

Accepted Preprint published online 18 December 2013 http://joe.endocrinology-journals.org DOI: 10.1530/JOE-13-0426
() 2014 Society for Endocrinology Printed in Great Britain 